https://doi.org/10.15407/dopovidi2021.03.086

УДК 581.584+ 581.55.574:59

В.I. Мельник, https://orcid.org/0000-0001-8315-8468

Національний ботанічний сад ім. М.М. Гришка НАН України, Київ

E-mail: melnykviktor6@gmail.com

\title{
Екотони і охорона флористичного різноманіття
}

Представлено членом-кореспондентом НАН України Н.В. Заіменко

Вивчення екотонів як унікальних осередків флористичного різноманіття є актуальним завданням екологічних досліджень. На основі детального аналізу умов місцезростань двох рідкісних і зникаючих видів, реліктів та ендеміків флори Свропи Daphne sophia Kalen (Thymeleaceae) ma Syringa josikaea J. Jacq. ex Rchb. (Oleaсеае), встановлена їх приуроченість до екотонів. Визначені закономірності формування, організачії та розвитку екотонів як унікальних місцезростань рідкісних $і$ зникаючих видів. Приуроченість ряду рідкісних видів до екотонів обумовлює лінійну або стрічкову просторову структуру їх популяцій. Антропогенний пресинг на екотони призводить до трансформації лінійних популящій у локальні ізольовані популяції. Щоб упередити зникнення рідкісних видів, ценотично пов'язаних з екотонами, їх популяції необхідно взяти під охорону, передбачивщи природоохоронний менеджмент і моніторинг за станом популяцій.

Ключові слова: місцезростання, популяція, угруповання, рідкісний вид, Daphne sophia, Syringa josikaea.

Розробка наукових основ охорони флористичного різноманіття є актуальним завданням екологічних досліджень. Особливої уваги потребують рідкісні та зникаючі види рослин, внесені до національних червоних книг і міжнародних червоних списків. Недостатня вивченість цих видів з еколого-ценотичного погляду є перешкодою для науково обгрунтованої охорони.

Стає очевидною необхідність охорони різноманіття екотонів як унікальних місцезростань рідкісних і зникаючих видів. Спочатку екотон розглядався як пояс напруженості між двома сусідніми угрупованнями. У наш час склалося чітке уявлення про екотони як про транзитну зону між двома або більше екологічними угрупованнями, яка має вигляд вузької витягнутої стрічки. До складу екотонів входять як види кожного із прилеглих угруповань, так і види, характерні тільки для самих екотонів [1]. У зв’язку з цим кількість видів і чисельність особин у популяціях деяких з них у екотонах є вищою порівняно з прилеглими угрупованнями. Це наводить на думку про особливу созологічну роль екотонів як унікальних осередків зростання рідкісних і зникаючих видів рослин.

Ци т у в ан н я: Мельник В.І. Екотони і охорона флористичного різноманіття. Допов. Наи. акад. наук Укр. 2021. № 3. C. 86-95. https://doi.org/10.15407/dopovidi2021.03.086 
В Україні, як і в інших країнах колишнього СРСР, екотони не були об'єктами ботанічних та екологічних досліджень. Класик радянської геоботаніки В.М. Сукачов писав, що неможливо вибирати пробні ділянки там, де ми маємо перехід від одного типу лісу до іншого. Потрібно намагатися, щоб ці ділянки якомога краще характеризували тип лісу. 3 таким традиційним підходом до вивчення рослинного покриву не могло бути й мови про наукові основи охорони рідкісних і зникаючих видів у екотонах, оскільки самі екотони лишалися поза рамками наукових досліджень.

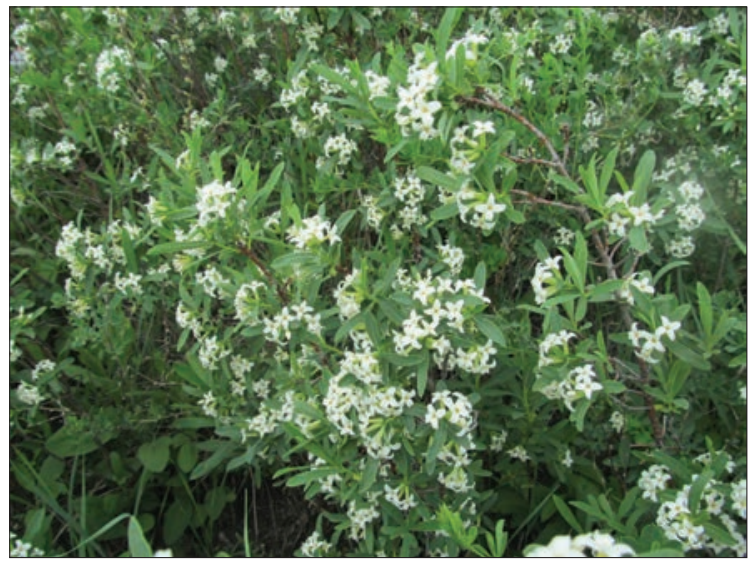

Puc. 1. Daphne sophia Kalen

В останні роки екотони інтенсивно вивчаються в усьому світі. Однак фітосозологічні аспекти лишаються слабо висвітленими у фаховій літературі.

За мету наших досліджень ставилося вивчення екотонів як унікальних осередків зростання рідкісних і зникаючих видів флори України та розробка наукових основ їх охорони.

Об'єкти та методика досліджень. Об'єктами досліджень були рідкісні і зникаючі види - ендеміки й релікти флори Європи Daphne sophia Kalen (Thymeleaceae) та Syringa josikaea J. Jacq ex Rchb. (Oleaceae). Умови місцезростань видів і стан їх популяцій вивчали за методиками еколого-ценотичного аналізу екотонів [1]. Польові дослідження проводили на території Закарпатської та Харківської областей у 2019-2020 pp.

Результати досліджень та іх обговорення. Встановлення закономірностей організації, розвитку і функціонування екотонів на межах фітоценозів та ландшафтів має важливе значення для науково обгрунтованої охорони флористичного різноманіття. Однак у літератуpi практично відсутні описи екотонів як місцезростань рідкісних і зникаючих видів рослин. Наводимо результати наших досліджень екотонних місцезростань двох рідкісних, ендемічних і реліктових видів флори України.

Daphne sophia (рис. 1) - рідкісний вид флори Європи, внесений до Червоних книг України і Росії та до Червоного списку Міжнародного Союзу Охорони Природи і Європейського Червоного списку [2-4].

У систематичному відношенні D. sophia близька до D. altaica Pall., D. caucasica Pall., D. taurica Kotov. Деякі дослідники [3] включають популяції D. sophia до D. altaica. Ми важаємо, що D. sophia є окремим, хоч і дуже близьким до інших видів роду Daphne ряду Alpina [5].

D. sophia - ендемік Середньоруської височини, ареал якого обмежений бассейном p. Сiверський Донець у межах Білгородської області Російської Федерації та Харківської області України. За весь період флористичних досліджень зафіксовано лише 23 локалітети D. sophia, більша частина з яких знаходиться на території Росії [6]. В Україні зафіксовані лише шість локалітетів, чотири з яких збереглися до наших днів [7].

Багато дослідників відносили $D$. сnеоrum до третинних реліктів. Обмеженість поширення цього виду на півдні Середньоруської височини, яка не покривалася зледеніннями, та численні знахідки викопного насіння цього виду в пліоценових відкладах є хорошим доказом його реліктової природи. Знайдені залишки насіння виду, близького до D. sophia та 
D. altaica, у місцях, де ці види зараз не зростають (Липецька, Рязанська, Тамбовська області Росії, Татарстан), свідчать про те, що в минулому існував єдиний природний ареал обох видів, який займав площу від Середньоруської височини до гір Алтаю. В антропогеновому періоді під впливом зледенінь відбулися диз'юнкції в ареалі, що поклало початок формуванню близькоспоріднених відособлених одна від одної рас роду Daphne cepiї Alpina [5].

У зв'язку із вищевикладеним точка зору про D. sophia як про адвентивну рослину, занесену на Середньоруську височину з Алтаю птахами або людиною [8], становить лише історичний інтерес.

У ботаніко-географічній літературі закріпилася точка зору про D. sophia як про супутника реліктових гірських або крейдових борів. Оскільки місцезнаходження виду приурочені не лише до окраїн соснових, а й дубових і дубово-соснових лісів, то він вважається також супутником дубових лісів та суборів.

Альтернативну точку зору висловив B.I. Талієв [8], згідно з якою D. sophia є елементом чагарникових заростей, не пов'язаних з крейдовими борами. Компромісну точку зору запропонував A.P. Мєшков [9] про те, що D. sophia в наш час зростає серед заростей лісових і степових чагарників по крутих схилах річкових долин та балок, корінними ж ценозами, до складу яких входив цей вид до інтенсивного впливу людини на природне середовище, були крейдові бори та субори.

Ні під час польових досліджень, ні за літературними даними не вдалося виявити жодного місцезростання D. sophia в плакорних лісах. Усі вони приурочені до окраїн лісових масивів на схилах балок або уступів других надзаплавних терас рік. Отже, точка зору про D. sophia як супутника борів та суборів є не зовсім коректною. Правильніше розглядати локалізацію цього виду на стику між лісовими і степовими угрупованнями та рослинністю крейдових відслонень. Оскільки D. sophia не витримує сильного затінення та сильного освітлення, вона зростає лише по окраїнах лісових масивів, уникаючи як чисто лісових, так i степових та крейдових екотопів. Степові схили не придатні для неї у зв'язку із задернінням, а крейдові відслонення - через відсутність грунтового покриву, відповідно, еколого-ценотична амплітуда виду не є надзвичайно широкою, як вважав А.Р. Мєшков [9], а навпаки, вона вкрай вузька на стику між лісовою, степовою та крейдовою рослинністю. Таким чином, місцезростання D. sophia являють собою екотони між трьома рослинними угрупованнями. Всі риси екотонів - проміжне положення між екосистемами, лінійна протяжність в одному напрямку і вузкість в іншому, наявність видів, характерних для кожного із трьох прилеглих угруповань, і видів, характерних тільки для самих екотопів, повною мірою виявляються в місцезростаннях D. sophia.

Виходячи з усього викладеного вище, неможливо погодитись з точкою зору Т.В. та А.В. Бережних [6] про те, що в недалекому минулому ареал цього виду як супутника борів і суборів був значно ширшим від сучасного, займаючи весь простір півдня Середньоруської височини. Ареал D. sophia, безперечно, був ширший від сучасного, однак як вид екотонів він займав лише вузькі екологічні ніші на стику трьох угруповань у долинах рік і балок. А отже, його популяції були стрічковими (лінійними). Вирубування лісів і лісопосадки на схилах, випасання худоби та видобуток крейди, виривання квітів і заготівля лікарської сировини - все це призвело до фрагментації лінійних популяцій та їх трансформації в ізольованій локальній популяції. 
У зв'язку з інтенсивним зведенням лісів Середньоруської височини в більшості місцезростань D. sophia відбулося заміщення лісової частини екотонів чагарниками. В результаті на місці лісово-степових екотопів, сформувалися чагарниково-степові екотони. До одного з таких екотонів приурочене місцезростання D. sophia в долині р. Вовча в околицях с. Мала Вовча у Вовчанському районі Харківської області. Це місцезростання приурочене до крутого правого берега р. Вовча (рис. 2). Місцезростання було виявлено і описано B.I. Талієвим [8]. Згідно з його описом, верхня частина схилу була покрита густими чагарниковими заростями Corylus avellana,

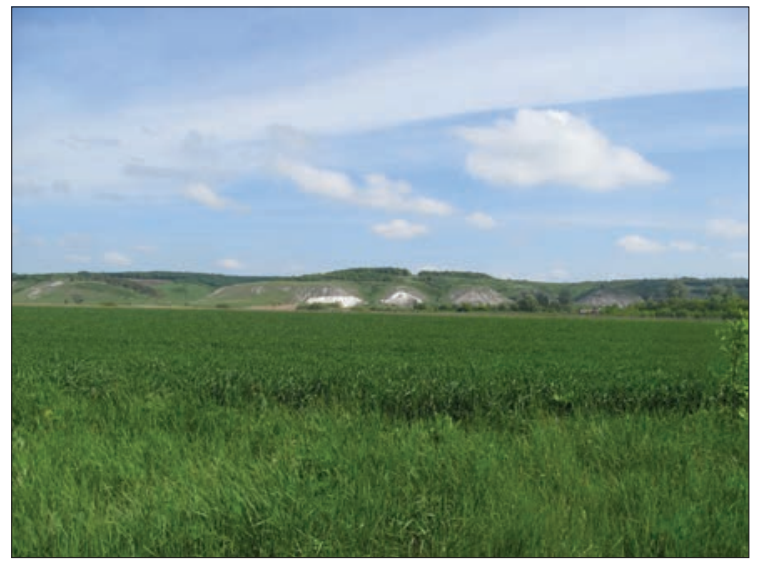

Puc. 2. Місцезростання Daphne sophia на крейдових схилах в долині р. Вовча (околиці с. Мала Вовча, Харківська область) Cerasus fruticosa, Euonymus verrucosus, Rhámnus cathártica з участю Caragana frutex, Viburnum opulus і окремих молодих дерев Acer tataricum та Quercus robur.

Рослинність нижньої частини схилу була представлена степовими та крейдовими угрупованнями. Більша частина схилу покрита степовою рослинністю з участю Adonis vernalis, Anemone sylvestris, Asparagus officinalis, Clematis integrifolia, Euphorbia procera, Fritillaria ruthenica, Galium tinctorium, Hieracium virosum, Polygonatum officinalis, Ranunculus polyanthemos, Silene nutans, Valeriana officinalis, Vicia herbacea.

На глинистих грунтах з близьким заляганням крейди зростали Andrósace koso-poljanskii, Gypsophilla altissima, Hyssopus cretaceous, Linum ukrainicum, Matthiola fragrans, Onosma simplicissinum, Polygala cretacea, Thymus cretacea.

Популяція D. sophia займала проміжне положення між чагарниковими та трав'янистими угрупованнями в середній частині схилу. В монодомінантних заростях D. sophia виявлені поодинокі рослини Chamaecytisus ruthenicus, Coronilla varia, Matthiola fragrans, Onosma simplicissinum, Pimpinella tragicum, Polygala comosa, Thalictrum minus.

Більш ніж через сто років після публікації В.І. Талієва [8] ми дослідили умови місцезростань виду в цьому локалітеті і не виявили жодних істотних змін. І в наш час популяція D. sophia займає проміжне серединне положення між чагарниками вище по схилу та степовими угрупованнями і крейдовими відслоненнями нижче по схилу. Верхня частина схилу покрита густими монодомінантними заростями Ramnus catharthica 3 незначною участю Caragana frutex, Cerasus fruticosa та Vinca herbacea.

Нижня частина схилу представлена переважно лучностеповим угрупованням классу Festuco-Brometea порядку Festucetalia valesiaca союзу Festucetion valesiaca асоціацією Carici humilis-Stipetum pennatae. Крім едифікаторів, до складу асоціації входять Adonis vernalis, Ajuga chia, Chamaecytisus ruthenicus, Clematis integrifolia, Crambe tataria, Jurinea calcarea, Linum ukrainicum, Nonea pulla, Onosma tanaitica, Polygala cretacea, Ranunculus illyricus, Ranunculus polyanthemos, Salvia verticillata, Thalictrum minus, Verbascum foeniceum.

Монодомінантні зарості D. sophia займають площу близько 770 м $^{2}$ в середній частині схилу. Вони настільки загущені, що інші рослини тут трапляються зрідка. 3-поміж них від- 
мічені Cerasus fruticosa, Caragana frutex, Galium boreale, Polygonatum multiflorum, Stipa pennata, Thalictrum minus, Vinca herbacea.

Дана локальна популяція являє собою єдиний клон вегетативного походження. На 1 м² припадає від 20 до 50 квітконосних стебел D. sophia.

B.I. Талієв [8] вказував, що D. sophia в даному локалітеті відзначається “стисненим ростом, короткими гілками та надзвичайно сильним квітуванням”. Така характеристика є актуальною для цієї популяції і в наш час.

Порівняння даних В.I. Талієва [8] з результатами наших досліджень свідчить про стабільне існування D. sophia в екотоні протягом останнього століття, при відсутності антропогенних впливів. Значна крутизна берега р. Мала Вовча в тому місці, де до нього приурочена популяція D. sophia, робить його недоступним для випасання худоби та сінокосіння. 3 таким станом ландшафтної екосистеми популяція виду і далі буде стабільною. На відміну від описаної вище популяції D. sophia, всі інші іiї популяції мають чітко виражену тенденцію до зниження чисельності. Аналіз стану популяцій D. sophia від XIX ст. до наших часів у Білгородській області Російської Федерації [6] виявив значні деградаційні зміни. Так, колись чисельна популяція в долині р. Сіверський Донець в околицях с. Пушкарне (тепер житловий масив м. Білгород) на початку XX ст. займала площу $200 \mathrm{~m}^{2}$, а через сто років лишилося лише три невеликі куртини по 10-15 квітконосних стебел у кожній. На правобережжі р. Оскол в околицях с. Стара Симонівка (Валуйський район), де на початку минулого століття D. sophia зустрічалась у великій кількості, в наш час збереглося не більше двох десятків низькорослих слаборозвинених рослин. В XIX ст. в урочищі “Бекарюковка” в околицях с. Михайлівка Щебекинського району на правобережжі р. Нежеголь D. sophia утворювала практично непрохідні зарості, в наш час виявлені лише окремі особини. В урочищі “Крейдяні стінки” біля с. Ровеньки від популяції, площа якої в 30 роках минулого століття становила 25 на 10 м, у наш час збереглася лише одна рослина.

Стан згаданих вище популяцій є найбільш критичним. Їх чисельність не перевищуе двох десятків особин. Чисельність особин в інших популяціях дещо вища, однак теж невисока - від кількох десятків до кількох сотень особин і ця чисельність неухильно зменшується $[3,6]$. Сдина популяція, чисельність якої становила близько тисячі особин, знаходилася в середній частині яру на узбережжі р. Айдар в околицях с. Ровеньки. На початку 30-х років минулого століття вона займала площу 25 на 15 м. На кінець минулого століття іiі площа значно збільшилась і характеризувалася такими прараметрами: довжина 180-200 м, ширина 15-20 м. Однак експансія дуба на колись безліссі частини схилів в останні роки є загрозою для існування цієї популяції.

Дещо вищими є показники чисельності особин виду в українських популяціях у Вовчанському районі Харківської області. У локалітеті 10 на 40 м поблизу с. Жовтневе Друге виявлено близько 600 рослин, біля с. Колодязне на площі в 1 га - 1500 рослин, біля с. Охримівка - близько 150 рослин $[2,4,7]$.

Отже, в цілому чисельність особин у популяціях D. sophia є вкрай низькою - від 1 до 1500 особин. Як вже вказувалося вище, всі популяції перебувають під сильним антропогенним пресингом. Половина популяцій виду вже зникла.

D. sophia підпадає під категорію зникаючих видів (EN) за критеріями Міжнародного Союзу Охорони Природи (IUCN, 1994). На жаль, збувається передбачення Б.М. Козо-По- 
лянського про те, що людська діяльність може призвести до повного знищення цього виду. Щоб унеможливити елімінацію нечисельних популяцій D. sophia, необхідно взяти під охорону всі місцезростання і проводити природоохоронний менеджмент, спрямований на недопущення антропогенних змін в екотонах.

Syringa josikaea (рис. 3) - рідкісний вид флори Свропи, внесений до Червоних книг України і Румунії, до Червоних списків МСОП та Свропи, до додатків Бернської конвенції [2, 10-12].

У систематичному відношенні $S$. josikaea близька до східноазійських видів S. villosa Vahl., S. wolfii C.K. Schneid. (деякі дослідники розглядають два останні види як підвиди одного виду, що підтверджено шляхом аналізу ДНК). Знахідки викопних решток S. josikaea у відкладах середнього міоцену Угорщини підтверджують точку зору про цей вид як третинний релікт. Вважається, що S. josikaea від'єдналася від своїх східноазійських родичів у холодному і сухому періоді плейстоцену. В минулому ареал $S$. josikaea був ширшим від сучасного, про що свідчать викопні рештки виду в інтергляціальних відкладах на сході Німеччини [13]. S. josikaea - ендемік флори Карпат. Диз’юнктивний

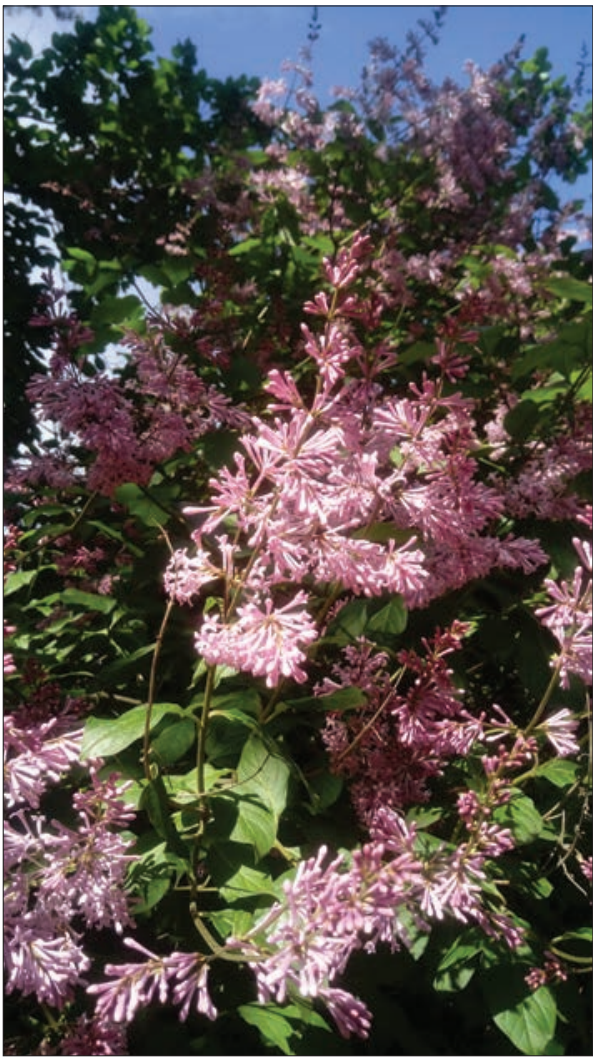

Puc. 3. Syringa josikaea J. Jacq. ex Rchb. ареал цього виду складається з двох частин, розташованих в Українських Карпатах та в горах Апусені в Трансильванії (Румунія). Усього зафіксовано лише 25 локальних популяцій S. josikaea: 17 - в Українських Карпатах і 8 - в горах Апусені. Вкрай незначні відмінності між українськими та румунськими популяціями S.josikaea дають підставу допустити, що диз’юнкція між ними виникла в післяльодовиковий період, а колонізація виду в Українські Карпати та в гори Апусені відбувалася з єдиного центру. Рефугіумом виду в льодовиковому періоді могла бути територія, яка включала в себе Українські Карпати та гори Апусені $[12,13]$.

Із 18 локалітетів $S$. josikaea, зафіксованих в Україні, 16 розташовані в Закарпатті в долинах річок Уж, Латориця, Ріка і два - в Прикарпатті, у Львівській області, в долині р. Стрий. Вони приурочені до поясу букових лісів на висоті 350-760 м² [3, 13, 14].

У Трансильванії зафіксовано вісім локалітетів $S$. josikaea в поясі букових лісів на висоті 450-1100 м у горах Апусені. Вони приурочені до долин рік Арієш (Arieș), Крішул Негру (Crişul Negru), основних приток річки Крішул Репеде (Crişul Repede) - Яд Валлей (Jad Valley), Стане де Веле (Stâna de Vale), Хенц Валлей (Hents Valley), Валеа Себешулі (Valea Sebeşului), Сомешул Калд (Someșul Cald) [10-12].

Умови місцезростань $S$. josikaea висвітлені в публікації Л.М. Фельбаби-Клушиної [14], згідно з якою їі угрупування генезисно пов'язані з альнетальним флорокомплексом. 3 цим навряд чи можна погодитися, оскільки, як зазначає сам автор, у місцезнаходженнях цього виду, крім гігрофільних видів, які вона відносить до альнетального флорокомплексу, тут 
зростають мезофільні види, які не мають жодного стосунку до цього комплексу. Це Aconitum moldavicum, Anemone nemorosa, Asarum europaeum, Carex sylvatica, Galanthus nivalis, Galeobdolon luteum, Mercurialis perennis, Paris quadrifolia, Polygonatum verticillatum, Salvia glutinosa, Sanicula europaea, Symphytum cordatum та інші види, які ценотично пов'язані із широколистяними лісами. В Українських Карпатах $S$. josikaea зростає не лише разом з двома видами вільхи Alnus glutinosama та Alnus incana, а й в угрупованнях Caltho-SyringosoSalicetum, де види вільхи відсутні. Крім того, $S$. josikaea частіше зростає не в чистих вільхових лісах, а у вільхово-ясенових лісах (ольсах) асоціацій Alneta (incanae)-Fraxinetum (excelsioris) - Syringoso (josikaea)-Caricosum (brisoides), Alneto (glutinosae)-Fraxinetum (excelsioris)Syringoso (josikaea)-Allium (ursinii), Alneto (glutinosae)-Fraxinetum (excelsioris)-Syringoso (josikaea)-Caricosum (tremulae), Alneto (glutinosae)-Fraxinetum (excelsioris)-Syringoso (josikaea)-Asarietum (europae) і навіть у монодомінантних ясенових лісах асоціацій Fraxinetum (excelsioris)-Syringoso (josikaea)-Petasitosum (albae). Отже, в Українських Карпатах місцезростання $S$. josikaea частіше трапляється у вільхово-ясенових, ніж в чистих вільхових лісах.

У вільхових лісах, як і в інших місцезростаннях в Українських Карпатах, S.josikaea зустрічається не будь-де, а лише зрідка на берегах лісових струмків і рік.

Місцезростання $S$.josikaea в басейні р. Ядулі (Jadului) в горах Апусені віднесено до субасоціації Syringetosum josikaea асоціації Pulmonario rubrae-Abieti-Fagetum-Syringetosum josikaea. До складу рослинного покриву входять як гігрофільні види заболочених лісів, так і мезофільні види широколистяних лісів. У Трансільванії S.josikaea входить також до складу асоціацій Carici brisoides-Alnetum, Telekio speciosae-Alnetum [15].

Отже, як в українській, так і в румунській частинах ареалу, S. josikaea приурочена до екотонів між зональними мезофільними лісами та лісо-болотними угрупованнями. Розміщені вздовж лісових струмків по окраїнах лісових масивів популяції цього виду є стрічковими (лінійними).

У зв’язку з усім викладеним вище точка зору про те, що сучасні місцезростання $S$. josi$k a e a$ є витісненими в несприятливі умови внаслідок антропогенного впливу, а в минулому вона зростала в більш оптимальних умовах, становить лише історичний інтерес. Оскільки S. josikaea є видом, ценотично пов'язаним зі специфічними екотонами, вона не могла зростати на плакорах. Безперечно, в минулому ареал цього виду був ширшим від сучасного, однак його популяції і в минулому розміщувались у вигляді стрічок вздовж річок та струмків. Вирубування лісів і заміщення іх пасовищами, будівництво дамб і створення водосховищ, прокладання доріг, гідромеліорації - все це призводить до трансформації стрічкових (лінійних) популяцій до локальних ізольованих.

Інтенсивний антропогенний пресинг ставить під загрозу існування більшості популяцій виду в Закарпатті. Так, у 1980-х роках площа популяції S. josikaea в урочищі Майдан (рис. 4) на території Підполозянського лісництва Воловецького держлісгоспу зменшилася від 1,0 га до 0,6 га внаслідок прокладання траси Київ-Чоп. Збережена частина популяцій перебуває під загрозою зникнення внаслідок проведення будівництва. Місцезростання в урочищі Черешньово перебуває під загрозою зникнення у зв’язку з його перетворенням у сміттєзвалище. Місцезростання в урочищі Романовичі підпадає під вплив осушувальної меліорації, а популяції в урочищі Міхнувець в околицях сіл Яблунів, Тисичів, Верхня Грабівниця, Жденієво перебувають під впливом перевипасу. В Прикарпатті відбувається ви- 
тіснення S. josikaea внаслідок заростання ялиною та вільхою сірою в пам'ятці природи “Бузок угорський” $[2,11,13,14]$.

У Румунії у зв’язку з прокладанням автошляху значно скоротилася чисельність популяцій S. josikaea в долинах рік Арієш (Arieș Riveri) та Валеа Себешулі (Valea Sebeşului). Прокладання залізниці вздовж р. Крішул Репеде (Crişul Repede) поблизу сіл Чуча (Ciucea), Негрені (Negreni), Лореу (Lorău) зруйнувало популяцію виду. До часткової руйнації популяції S. josikaea призвело будівництво дамб і створення водосховищ в долинах рік Себешулі (Sebeşului), Сомешул Калд (Someșul Cald), Валеа Ядулуй (Valea Jadului) [10, 11].

Поблизу ряду населених пунктів Верхня Грабівниця, Підполоззя, Климець в Україні та Болога (Bologa), Чуча (Ciucea), Транішу (Tranişu) в Румунії рослини $S$. josikaea викопуються і пересаджуються на присадибні ділянки, а суцвіття вириваються на букети $[11,14]$.

В зв’язку зі специфічними умовами місцезростань та інтенсивним антропогенним пресингом на популяції S.josikaea вони є вкрай малочисельними і займають невелику площу. В Україні S. josikaea охороняється в Ужанському природному національному парку і в пам’ятках природи “Бузок угорський” у Воловецькому районі Закарпатської області та у Сколівському

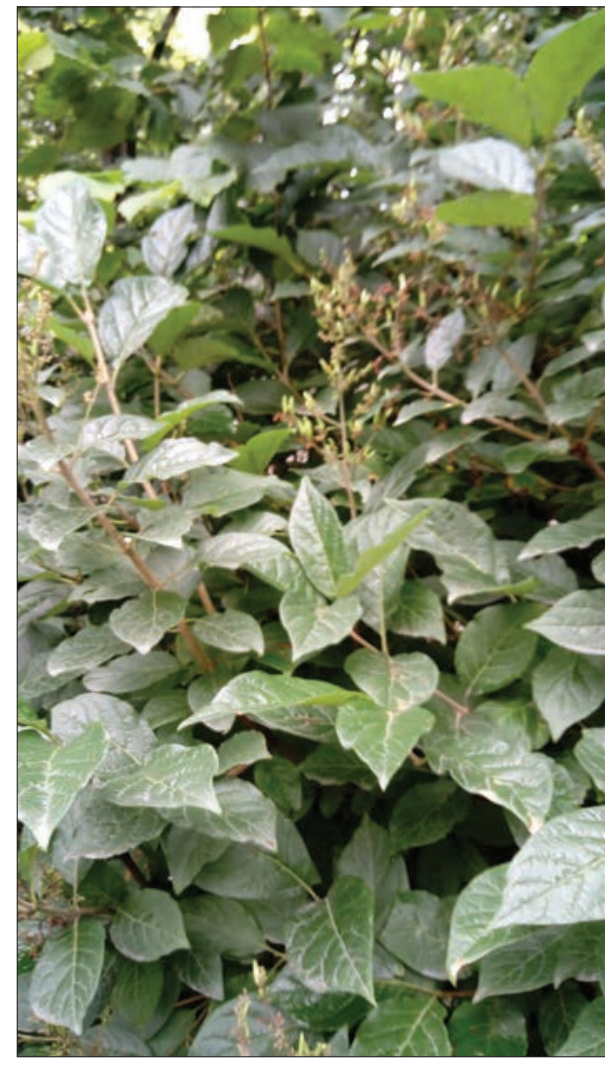

Puc. 4. Популяція Syringa josikaea в урочищі Майдан (Підполозянське лісництво, Закарпатська область) районі Львівської області [2], в Румунії - в національному парку Апусені [10, 11]. Зважаючи на високу цінність генофонду $S$. josikaea, всі вони потребують охорони ix situ і природоохоронного менеджменту, який би сприяв виживанню популяцій в умовах антропогенного тиску на екотони.

Детальний аналіз екотонів двох рідкісних реліктових і ендемічних видів флори Свропи показав, що екотони є їх первинними місцезростаннями, а не якимись вторинними оселищами, куди вони були витиснені внаслідок антропогенного пресингу. В зв'язку з цим їх охорона повинна бути спрямована не на пошуки первинних локалітетів у корінних угрупованнях, а в забезпеченні збереження вузьких смуг екотонів, з якими вони пов'язані екологічно, ценотично та генезисно. Оскільки екотони надзвичайно чутливі до антропогених впливів, створення природо-заповідних територій для збереження всього різноманіття рідкісних і зникаючих видів, пов'язаних з ними ценотично, є актуальним завданням фітосозології. Однак у ряді випадків абсолютна заповідність рідкісних видів у екотонах призводить до негативних наслідків. Тому необхідний природоохоронний менеджмент, спрямований на сприяння виживанню популяцій рідкісних видів і постійний моніторинг за ї станом.

За сприяння у проведенні польових досліджень автор висловлює вдячність завідувачу кафедри біологї та хімї Закарпатського угорського інституту ім. Ференща Ракоці ІІ канд. 
біол. наук Е. Когут і канд. біол. наук Т. Любці, директору ботанічного саду Харківського національного університету ім. В.Н. Каразіна О.О. Альохіну та старшому науковому співробітнику Украӥнського НДІ лісового господарства та агролісомеліоращї ім. Г. Висоцького М.В. Баніку.

\section{ЦИТОВАНА ЛІТЕРАТУРА}

1. Ecotones between forestand and grassland: Myster R.W. (Ed.). New York: Springer, 2012. 327 c.

2. Червона книга України. Рослинний світ: Дідух Я.П. (ред.). Київ: Глобалконсалтинг, 2009. 912 с.

3. Красная книга Российской Федерации (Растения и грибы): Трутнев Ю.П. (ред.). Москва: Товарищество научных изданий КМК, 2008. 855 с.

4. Melnyk V. Daphne sophia. The IUCN Red List of Threatened Species. e.T184432A82763. https://doi.org/ 10.2305/IUSN.UK.2011-1.RLTS.T165278A827577763.en. Downloaded on 02 March, 2016.

5. Melnyk V. Distribution and plant communities of Daphne cneorum and Daphne sophia in Ukraine. Thaiszia. J. Bot. 1996. 6. P. 49-66.

6. Бережная Т.В., Бережной А.В. Волчеягодник Софии и его география на юге Среднерусской возвышенности. Вестн. ВИВТ. 2017. № 2. С. 22-32.

7. Банік М.В., Тверетинова В.В., Волкова Р.С., Атемасова Т.А., Атемасов А.А., Брезгунова О.О., Влащенко А.С., Гончаров Г.Л., Коноваленко С.В., Скоробогатов В.М., Скоробогатов С.В., Целіщев О.Г. Нові місцезнаходження Daphne sophia Kalen. (Thymeleaceae) в Україні. Укр. бот. журн. 2007. 64, № 4. C. 565-569.

8. Талиев В.И. О Daphne sophia Kalen. Тр. Об-ва испыт. природы при Харьк. ун-те. 1912. 45. С. 95-152.

9. Мешков А.Р. Районы флоры и известняковых обнажений Среднерусской возвышенности. Ботан. журн. 1951. 36, № 3. C. 246-257.

10. Cartea roșie a plantelor vasculare din Romania: Dihoru G., Negrean G. (Ed.). București: Editura Academiei Române, 2009. 316 p.

11. Höhn M., Lendvay B. Syringa josikaea. The IUCN Red List of Threatened Species 2018. e.T162267A99428926. https://doi.org/10.2305/IUCN.UK.2018-1.RLTS.T162267A99428926.en

12. Lendvay B., Kadereit J.W., Westberg E., Cornejo C., Pedryc A., Höhn M. Phylogeography of Syringa josikaea (Oleaceae): Early Pleistocene divergence from East Asian relatives and survival in small populations in the Carpathians. Biol.J. Linn. Soc. 2015. 119, № 3. C. 689-703. https://doi.org/10.1111/bij.12499

13. Kohut E. In vitro propagation and survey of Leucojum aestivum L. and Syringa josikaea Jacq. Fil. ex Rchb. originating from natural stands of Transcarpathia: PhD thesis / Budapesti Corvinus Egyetem. Budapest, 2013.

14. Фельбаба-Клушина Л.М. Фітоценологічна характеристика та охорона угрупувань Syringa josikaea Jacq. (Oleaceae) в Українських Карпатах. Укр. бот. журн. 2005. 62, № 4. С. 484-494.

15. Burescu L.I.N. Research of ecological genetics on European beech-Silver fir stand and Norway spruce-European beech-Silver fir stand with Hungarian lilac (Syringa josikaea) in the Apuseni Mountains, Valea Iadului Valley Basin. association Pulmonario rubrae-Fagetum, sub-association Syringetosum josikaeae. Analele Universității din Oradea, Fascicula: Protecția Mediului. 2018. 31. P. 107-120.

Надійшло до редакції 19.04.2021

\section{REFERENCES}

1. Myster, R. W. (Ed.). (2012). Ecotones between forestand and grassland. New York: Springer.

2. Diduch, J. P. (Ed.). (2009). Red Data Book of Ukraine. Vegetable Kingdom. Kyiv: Globalconsalting (in Ukrainian).

3. Trutnev, Yu. P. (Ed.). (2008). Red Data Book of the Russian Federation (Plants and Fungi). Moscow: Community of scientific edition KMK (in Russian).

4. Melnyk, V. (2016). Daphne sophia. The IUSN Red List of Threatened Species. e.T184432A82763. https:// doi.org/10.2305/IUSN.UK.2011-1.RLTS.T165278A827577763.en. Downloaded on 02 March, 2016.

5. Melnyk, V. (1996). Distribution and plant communities of Daphne cneorum and Daphne sophia in Ukraine. Thaiszia. J. Bot., 6, pp. 49-66.

6. Berezhnaya, T. V. \& Berezhnoy, A. V. (2017). The Daphne sophia and its geography in the south of the Central Russian Upland. Vestnik VIVT, № 2, pp. 22-32 (in Russian). 
7. Banik, M. V., Tveretinova, V. V., Volkova, R. E., Atemasova, T. A., Atemasov, A. A., Bresgunova, O. O., Vlaschenko, A. S., Goncharov, G. L., Konovalenko, S. V., Skorobogatov, V. M., Skorobogatov, E. V. \& Tselischev, A. G. (2007). New localities of Daphne sophia Kalen. (Thymeleaceae) in Ukraine. Ukr. Botan. Journ., 64, No. 4, pp. 565-569 (in Ukrainian).

8. Taliev, V. I. (1912). About Daphne sophia Kalen. Trudy Kharkovskogo obshchestva estestvoispytateley. 45, pp. 95-152 (in Russian).

9. Meshkov, A. R. (1951). Areas of flora of chalk and limestone outcrops of the Central Russian Upland. Botan. zhurn., 36, No.3, pp. 246-257 (in Russian).

10. Dihoru, G. \& Negrean, G. (Ed.). (2009). Cartea roșie a plantelor vasculare din Romania. București: Editura Academiei Române.

11. Höhn, M. \& Lendvay, B. (2018). Syringa josikaea. The IUCN Red List of Threatened Species. e.T162267A99428926. https://doi.org/10.2305/IUCN.UK.2018-1.RLTS.T162267A99428926.en

12. Lendvay, B., Kadereit, J. W., Westberg, E., Cornejo, C., Pedryc, A. \& Höhn, M. (2015). Phylogeography of Syringa josikaea (Oleaceae): Early Pleistocene divergence from East Asian relatives and survival in small populations in the Carpathians. Biol. J. Linn. Soc., 119, No. 3, pp. 689-703. https://doi.org/10.1111/bij.12499

13. Kohut, E. (2013). In vitro propagation and survey of Leucojum aestivum L. and Syringa josikaea Jacq. Fil. ex Rchb. originating from natural stands of Transcarpathia. (PhD thesis). Corvinus University of Budapest. Budapest, Hungary.

14. Felbaba-Klushina, L. M. (2005). The phytocoenotic characteristics and protection of the communitys $S y$ ringa josikaea Jacq. (Oleaceae) within the Ukrainian Carpathians. Ukr. Botan. Journ., 62, № 4, pp. 484-494 (in Ukrainian).

15. Burescu, L. I. N. (2018). Research of ecological genetics on European beech-Silver fir stand and Norway spruce-European beech-Silver fir stand with Hungarian lilac (Syringa josikaea) in the Apuseni Mountains, Valea Iadului Valley Basin. association Pulmonario rubrae-Fagetum, sub-association Syringetosum josikaeae. Annals of the University of Oradea, Fascicle: Environmental Protection, 31, pp. 107-120.

Received 19.04.2021

V.I. Melnyk, https://orcid.org/0000-0001-8315-8468

M.M. Gryshko National Botanical Garden of the NAS of Ukraine, Kyiv

E-mail: melnykviktor6@gmail.com

\section{ECOTONES AND CONSERVATION OF PLANT DIVERSITY}

Investigation of ecotones as uncial habitats of plant diversity is an actual problem of ecological researches. Based on a detailed analysis of the habitats of two rare and endangered, relic, and endemic species of the European flora Daphne sophia Kalen (Thymelaeaceae) and Syringa josikaea J. Jacq. ex Rchb. (Oleaceae), the confinement of these species to ecotones are revealed. The patterns of the formation, organization, and development of the ecotones as unical habitats of rare and endangered species are established. The tinning of some rare species to ecotones is specified linear or tipe spatial structure of their populations. The anthropogenic pressure leads to a transformation of linear populations to local isolated ones. So, to prevent the extinction of rare species from ecotones, their populations need to be under protection. At the same time, it is necessary to carry out the environmental management and the monitoring the state of population.

Keywords: habitate, population, community, rare species, Daphne sophia, Syringa josikaea. 